\title{
Projeto de Extensão Ressurgir: Informação na Promoção À Saúde
}

\author{
Paula, Eliane Rodrigues dos Santos de; Souza, Ândrea Cardoso de \\ Universidade Federal Fluminense - elianeiffmacae@gmail.com
}

Introdução: nos dias atuais, conferimos através da mídia uma realidade assustadora: o aumento da violência em ambiente escolar, tendo a sua origem muitas vezes relacionada ao uso indiscriminado de substâncias psicoativas (SPAs). Justificativa / Relevância: Conhecermos a situação de consumo de substâncias psicoativas por parte de comunidade de uma instituição de ensino na cidade Macaé; ações de promoção à saúde e prevenção ao uso de SPAs são necessárias. a maneira de enfrentamento quanto aos problemas causados pelo uso abusivo de substâncias psicoativas, muitas vezes não passa pela cessação do uso, mas sim pela "Redução de Danos como política de prevenção e assistência dos problemas relacionados ao uso de drogas psicoativas" (CRUZ, SÁAD e FERREIRA, 2003), e esta estratégia nos remete a uma discussão, e se faz necessário um consenso por parte de todos os atores envolvidos na questão, aspectos diversos devem ser observados tais como, fatores culturais, sociais, econômicos, políticos, de caráter moral e ético. Objetivos: 1) Projeto Ressurgir visa prestar esclarecimentos e ações a toda comunidade escolar (corpo docente, administrativo, pais e alunos) explicando o que é (realmente) e como está para a sociedade o uso de substâncias psicoativas nos dias de hoje, as suas várias "faces" e disfarces, trabalhando para formar multiplicadores em conscientização e detecção quanto ao problema, desmistificar de que todo usuário de SPAs é uma pessoa "sem vergonha", "mau caráter", e que não precisa de ajuda. Metodologia: para alcançarmos os objetivos propostos, utilizaremos folhetos explicativos (com conteúdo simples e ilustrado), palestras com profissionais que já trabalham com a demanda em instituições de saúde (servidores e responsáveis), e com apresentações culturais, como música, teatro, oficinas assim como depoimento de ex-usuários em tratamento. Resultados: no decorrer de 4 anos de implantação na instituição de ensino, resultados positivos foram observados tais como: pessoas antes marginalizadas buscaram tratamento e voltaram a serem ativas e saudáveis, e em relação ao espaço cultural que foi criado a partir do projeto. Conclusão: Concluímos que ao discutir saúde em ambiente escolar através da arte e cultura, humanizamos as intervenções junto aos usuários de SPAs de toda a comunidade da instituição de ensino.

Paula, Eliane Rodrigues dos Santos de; Souza, Ândrea Cardoso de. Projeto de Extensão Ressurgir: Informação na Promoção À Saúde. In: Anais do Congresso Internacional de Humanidades \& Humanização em Saúde [= Blucher Medical Proceedings, num.2, vol.1]. São Paulo: Editora Blucher, 2014. ISSN 2357-7282

DOI 10.5151/medpro-cihhs-10283 